\title{
TRANSATLANTIC RELATIONSHIP BETWEEN THE EUROPEAN UNION AND THE UNITED STATES WITH A SPECIAL FOCUS ON THEIR APPROACHES TOWARDS MIDDLE EAST AND NORTH AFRICA REGION IN THE POST-COLD WAR ERA: FROM COMPETITION TO COOPERATION*
}

\section{Aylin Ünver NOI**}

\section{Abstract:}

This article assesses the transatlantic relationship between the European Union (EU) and United States (US) by focusing on their role in the international arena particularly in the Middle East and North Africa region(MENA) In this connection, security concerns, interests and aims of these two powers in this region, their different approaches and the factors which leads to divergences in their approaches to this region, rivalry between the EU and the US, and finally changing international environment which might lead to closer relationship between these two powers are evaluated.

Keywords: Transatlantic relationship, military power, civilian power.

\section{Özet:}

Bu makale Avrupa Birliği (AB) ve Amerika Birleşik Devletleri (ABD) arasındaki transatlantik ilişkileri, onlarin uluslararast arenadaki rollerine özellikle de Ortadoğu ve Kuzey Afrika Bölgesi'ne odaklanarak değerlendirmektedir. Bu bağlamda, güvenlik endişeleri, bu iki gücün bölgedeki çıkar ve amaçları, bu bölgeye karşı farklı olan yaklaşımları ve yaklaşımlarındaki farklılıklara neden olan faktörler, $A B$ ve $A B D$ arasındaki

\footnotetext{
* This article is derived mainly from a part of the author's book entitled "The EuroMediterranean Partnership and the Broader Middle East and North Africa Initiative: Competing or Complementary Projects?", which will be published by University Press of America, Inc. A Member of Rowman \& Littlefield Publishing Group.

"* Ph.D., researcher and author.
} 
rekabet, ve son olarak da değissen ve bu iki güç arasında daha yakın bir iliskiye neden olabilecek uluslararası ortam değerlendirilmektedir.

Anahtar Kelimeler: Transatlantik İlişkileri, askeri güç, sivil güç.

\section{Introduction:}

The Middle East and North Africa region has become the central focus of the US and the EU diplomatic relations. However, geographic proximity/distance of the EU and the US and their different historic, economic and demographic links with this region hinder them to achieve forging a common approach to this region. On the other hand, the Middle East and North Africa is likely to be an area which will determine the future of transatlantic relations between the EU and the US (Daalder, Gnesotto \& Gordon, 2006: 1, 2).

Their different perceptions, divergent and sometimes complementary interests shaped their approaches towards this region and affected transatlantic relationship. Although the security interests of the EU and the US were more or less the same during the Cold War period, it was possible to witness differences in perceptions and divergent interests which effects their approaches to this region. The EU's Middle East approach after the first Oil Crisis of 1973; and the EU's Iran policy based on "engagement" which is contrary to the US' "isolation" policy after the first decade of the Revolution are all examples to these different perceptions, divergent interests and approaches, which in turn led to transatlantic rifts and time to time loosened transatlantic solidarity. The reason lying behind these transatlantic rifts is hidden in transatlantic competition which has been mostly denied by the EU and the US.

At the time of Bush administration, the rift has been exacerbated and policy differences over the following issues contributed to this exacerbation: 1) treatment of suspect individuals in the US and suspect terrorist fighters held in Guantanamo Bay naval station in Cuba; 2) the US' embrace of preemptive military action (War in Iraq) as a foreign policy doctrine and 3) finally neglect and imbalance in the US' policy towards the Arab-Israeli peace process which has been seen as factor of risk by the EU (Hamilton, 2004: 71). 
This article evaluates the aims and interests of these two powers, their foreign policy instruments with a focus on "civilian power" EU and "military power" US concepts. It also provides a brief history of transatlantic relationship and an analysis of rivalry between the US and the EU in order to find out whether there is a shift from competition to cooperation between them in the Middle East and North Africa region.

\section{The Aims and Interests of the EU and the US in the Middle East and North Africa Region}

The EU's and the US' interests in the region largely converge rather than diverge as long as the core interests are concerned, such as energy security, stability and prosperity through democratization and liberalization of this region to maintain secure flow of oil and gas at reasonable prices, for selling their goods in these liberalized markets, preventing spread of WMD, terrorism etc. (Daalder, Gnesotto \& Gordon, 2006: 1). As stated in the European Commission's European Union-United States Relations document, "both the EU and the US share common interests in developing coherent strategies in order to promote peace and stability, to create conditions for harmonious economic development in the wider world and to promote the stability of the international trade, financial and monetary systems, as well as the economic integration of countries in transition and developing countries'(European Union-United States Relations: sheet 2).

Besides shared security concerns of the EU and the US, they have economic concerns due to their dependence on the oil of this region. Europe imports more than $30 \%$ of its oil from this region whereas the US imports about $10 \%$ of its oil from this region. One of the shared interests between the US and the EU is thus energy security, or in other words, maintaining free flow of oil from this region at reasonable prices (Khalilzad, 1998: 196, 198).

Another shared interest between the EU and the US is regional stability and prosperity of this region. In this respect, promoting economic liberalization and democracy which might lead to economic prosperity and regional stability to this region were determined as one of the aims of both US National Security Strategy (2002) and the Europe's Security Strategy (ESS) (2003). These interests are interrelated to each other since internal instability threatens potential economic growth due to reduction in the foreign investment in regional actors. Instability also threatens free flow of oil at reasonable prices since conflicts may destroy key oil production and transportation facilities. The worst scenario related to this is that use of oil 
as a weapon against major importers by the extremist groups which might possess the control of countries of this region. Moreover, internal instability may sometimes harm the relationship of these countries with the EU and the US. For instance, internal conflict in Algeria in the beginning of the 1990s resulted in targeting of all or some of the western living in this country (Khalilzad, 1998: 198).

Promoting stability to the Middle East and North Africa is more important for the EU due to its geographic proximity. Problems of this region might be transformed easily into the problems of the EU through immigration from the countries of this region to EU member states along with existing immigrants living in the EU member states (Satloff, 1997: 19; Khalilzad, 1998: 201-203). ${ }^{1}$

One of the shared interest between the EU and the US is slowing down the introduction of weapons of mass destruction (WMD) and creating a Middle East free zone weapons of mass destruction (nuclear, biological and chemical weapons) in order to eliminate acquisition of such weapons by terrorist groups (Blackwill \& Stürmer, 1997: 299). In addition to this, acquisition of nuclear power by one of the countries of this region might create a domino effect on others which is totally controversy for the interests of both the US and the EU.

Along with above mentioned shared interests such as energy and regional stability between the EU and the US, the US also has another core interest which is preserving the security of Israel in this region. The US and Israel relationship is different from any other the US has in the world whereas the EU's tie with Israel is not as strong as those between Israel and the US (Satloff, 1997: 10, 11). ${ }^{2}$ Although both the EU and the US have

\footnotetext{
${ }^{1}$ Increasing number of illegal immigrants and the increasing differences between the immigrants living in the EU member states and the Europeans and its effects on alienation to each other also affects internal political stability in the EU member states through increasing xenophobia and strengthening the hands of extreme right parties, on the one hand, leading to potential emergence of North African origin immigrants' revolts as we witnessed in France and some other EU member states when two young Algerians died because of the French police, on the other hand (Ünver Noi, 2007: 12).

2 Arab oil boycott against the Netherlands following the Yom Kippur War in 1973 and the first oil crisis made a great change in the Europe's overall relations with the Arab world and the Israel as a community composed of industrialized countries which strongly need oil for their economic prosperity. It thus balanced its approach to Israel, one the one hand, its Arab neighbors, on the other hand (Rhein, 1997: 49).
} 
favored peace between Arabs and Israelis, their approaches have been different and sometimes the Arab-Israeli conflict became a source of contention between the US and the EU (Khalilzad, 1998: 196-197).

The US also has a strong interest in preventing any single power (outside this region like Soviet Union during the Cold War period or a potential regional power) from controlling this energy rich region (Satloff, 1997: 10). As it is argued by some, this also explains the hidden agenda behind the US' invasion of Iraq. As Chomsky (2007) stated "If Iraq were an island in the Indian Ocean and its main export were pickles, not petroleum, Iraq would not be invaded by the US" (p. 162).

\section{Foreign Policy Instruments used by the EU and the US in the Middle East and North Africa Region}

Since the Six Days War of 1967 and the British withdrawal from Aden in 1971, The US and Europe have maintained an informal division of labor regarding the Middle East. Hence, the US has been recognized as a leader with two main regional projects; promoting Arab-Israeli peacemaking and maintaining Gulf security, whereas Europe has limited roles such as supporting and financing US initiatives, pursuing particularistic economic and political interests in the region. In other words, Europe has a secondary status in the Middle East in spite of its geographic proximity, historical connection and organic economic and demographic links to the area (Satloff, 1997: 7-8).

Their different approaches to the region first emerged after the oil crisis of 1973. The outbreak of the first oil crisis in 1973 and the other developments such as collapse of the Bretton Wood system (1971-73) led Europe to take measures against a prospective crisis and made their approaches to the Middle East different from those of the US (Ünver Noi, 2005: 83, 96). ${ }^{3}$ Regional stability has become a matter of increasing priority for the EU due to Europe's dependence on the Middle East's energy resources. Its major instruments to that end became trade liberalization, cooperation, and policy dialogue (Rhein, 1997: 45). The EU's policy of "engagement", which is contrary to the US' policy of "isolation and "dual containment" of Iraq and Iran, can also be explained from this perspective.

\footnotetext{
${ }^{3}$ Today, if the eight countries of the Gulf that hold $40 \%$ of known global oil and 25 $\%$ of known global gas reserves were to stop their exports to the rest of the world for just two months, the global system would nearly collapse: oil and gas price would increase tremnendously due to energy scarcity (Rhein, 1997: 41).
} 
The EU member states sometimes perceive the threats of this region differently than the US. On the other hand, they sometimes have the same threat perception. In the post- 9/11 era, the US National Security Strategy shares a fairly similar analysis of security threats with the ESS (2003). Terrorism, proliferation of weapons of mass destruction, regional conflict, state failure and organized crime are challenges for both sides of the Atlantic. However, the foreign policy instruments used by the US and the EU for dealing with the common threats are different. In other words, the EU does not share the US approach to dealing with these threats since the US and the EU have significantly different views on the use of force, legitimacy and the right way to solve problems in the Middle East.

The US prefers rapid transformation of the region through using its "military power" contrary to the EU's preference for gradual change and immediate focus on conflict resolution through using its "civilian power". As stated in the ESS, the EU prefers to confront these new threats by using much more innovative and transnational approaches based on "civilian power" understanding and using civilian instruments rather than by using purely military means due to the feature of these new threats -more diverse, less visible, less predictable and transboundry- and inability of the EU to confront them by using purely military means (ESS, 2003: 3, 7). In this respect, the EU gives much more its attention to overall socio-economic stability particularly in this region in order to cope with the threats stemming from this region. In this connection, it stressed economic instruments to ensure reconstruction. In order to promote reform and ensure stability in this region, the EU focuses much more trade and development policies along with assistance programmes, conditionality and targeted trade measures as powerful tools (Sjursen, 2005: 4, 5).

In the post-9/11 era, the EU preferred to use civilian instruments whereas the US gave priority to using military instruments along with others. To highlight the EU's uniqueness, comparisons are often made between it and the US. Contrary to the US, the EU believes that diplomacy can produce the best result. There is no transatlantic consensus on making military force part of the democratization process in the region due to the belief that military action will simply make the situation worse in these regions (Blackwill \&

\footnotetext{
${ }^{4}$ The EU has been described as a 'civilian power'(Duchéne, 1972) which refers to the EU's pursuit of distinct foreign policy principles: the acceptance of the necessity of cooperation with others in the pursuit of international objectives such as respect for international law and a concentration on non-military, primarily economic means, to secure goals (Smith, 2003: 15).
} 
Stürmer, 1997: 6; Daalder, Gnesotto \& Gordon, 2006: 219; Khalilzad, 1998: 207). However, it is worth to mention that some EU member states became part of the US coalition "fight for freedom of Iraq". This policy of the EU might be partly explained by the absence of the EU's efficient military power to use, the EU's limited capability to use its military power and the need for alternative ways to become a global actor which can change the behavior of other actors of the international scene by using its civilian power and/or soft power instead of military power. Also, the conflicting EU and the US approaches regarding the use of force can be explain as the widening gap between the military doctrine (preemptive and preventive war) and capabilities of the US and those of the EU. The US defence expenditures are almost what three main powers of the EU (Britain, France and Germany) had spent in 2000. This is a facilitating factor of the US' use of "military power" to make regime changes in unfriendly regimes of the US in this region (El-Sayed Selim, 2004: 228; Walt, 2005: 34). This rapid force projection over long distance ability enables the US to act unilaterally (Blackwill \& Stürmer, 1997: 7). In comparison to the emphasis of the US on unilateralism, the EU prefers to pursue a multilateral approach to global security. It relies on multilateralism and international law, which are at the core of the ESS and "civilian power" Europe, to resolve conflicts rather than on unilateral measures (Elgström \& Smith, 2006: 3).

The EU prefers persuasion and positive incentives rather than coercion. Also, it prefers constructive engagement rather than isolation (Elgström \& Smith, 2006: 3). The EU mostly adheres to "soft power" and tries to be a "force of attraction" by using its full membership and/or partnership card (El-Sayed Selim, 2004: 228). The EU's "soft power", in other words "force of attraction" and the EU's "civilian power" used to shape the countries in the EU's own image is the basis of EU's foreign and security policy although it has efforts to develop its military capabilities through establishment of European Security and Defence Policy (ESDP) which also make the EU independent from US. ${ }^{5}$

Since the 9/11 terrorist attacks, the US perceived terrorism as the main security threat and that threat can only be dealt with through traditional military instruments. The Bush Administration opted for military power

\footnotetext{
${ }^{5}$ Although there are arguments that if the EU develops its "military power", it loose its "civilian power", Maull (2005) argues that having military power does not mean that the EU will loose its "civilian power". According to Maull (2005), if it is necessary, military power might be applied collectively by obtaining international legitimacy only in the pursuit of 'civilizing' international relations (781).
} 
over civilian power which is "hard power" strategy instead of "soft power" in Nye's terms. "The US foreign policy which was based on "deterrence" and "containment" between the end of the Cold War and the September 11 th terror attacks, thus replaced by Bush Doctrine of war which is based on "preemptive" and "preventive" war. This new foreign policy of the US was also unilateral since 'Bush Administration was more skeptical of existing international institutions including the US' Cold War alliances and far more willing to -go it alone- in foreign affairs' (Walt, 2005: 31). Briefly, the US foreign policy action was based on military preemption, unilateral action, military superiority and a commitment to "extending democracy, liberty, security to all regions" (Kreft, 2005: 70, 71) since the large and diverse economy of US gave it a considerable political leverage and enabled the US to create and equip a powerful military force and make it the dominant military power (Walt, 2005: 32-34).

The US first used its military power in Afghanistan right after terrorist attacks to the World Trade Centers and Pentagon to fight against terrorism. Afghanistan was the right place to do that since Taliban government had provided bases for Osama Bin Laden and Al-Qaeda terrorists. The second target was Iraq with the claim based on WMD development. Without having a UN mandate, the US launched its unilateral war on Iraq in March 2003 by adding that they fight for "freedom of Iraq". This operation took place after launch of the US democratization agenda in the Greater Middle East region with the initiation of MEPI (2002) as a part of Bush Doctrine.

The US believed that there was a need to use force in order to cope with the problems of the Middle East and North Africa region. Yet, the US realized that making externally enforced regime changes using military power is not sufficient to tackle the root causes of the structural problems which threaten the interests of the west. Moreover, the US preference for using military power particularly in Iraq harmed the US image and increased anti-US sentiments in the region. The necessity to have a multilateral civilian approach to this region emerged and led to emergence of the US-led BMENA project in 2004. With this development, the US used its military power -"hard power"-, through sanctions and military invasions, as a complementary to its civilian power-"soft power"- based on free trade

\footnotetext{
${ }^{6}$ When one country gets other countries to want what it wants--might be called cooptive or soft power in contrast with the hard or command power of ordering others to do what it wants (Nye, 1990: 166).
} 
agreements (MEFTA), financial aids (MEPI), development projects (BMENA) etc. There was a belief that both roles complement each other as the soft security role facilitates the hard security one. In this respect, the US carried out military agenda as an instrumental to its political goal which is democratization of the region. In other words, the US used military approach to complement its political/civilian approach. However, military power used by the US particularly against Iraq with the claim that it develops WMD undercut the effect of its civilian power or in Nye's term "soft power" to transform the countries of this region into "democratic" one (Nye, 2006).

The US approach to this region which is mostly based on its "military power" was criticized by the EU as well as Arab world. Developments in Iraq indicate that it would be a vague assumption to believe the US claim that 'democratic Iraq through the US military intervention guarantees peace and stability and prevents emergence of threats from this country'. From this perspective, the war in Iraq could not achieve a rapid and positive transformation as a result of policies of Bush. As Ikenberry stated the neoimperial grand strategy of Bush administration triggered antagonism and resistance that will leave the US in a more hostile, divided and less secure world (Ikenberry, 2002: 45). In other words, Bush Administration failed to combine "soft power" (civilian power) and its "hard power" (military power) into a winning strategy (Nye, 2006).

With the Obama Administration, there are some signals of shift of the US' policy from "military power" to "smart power" which combines "hard power" and "soft power" together. In other words to use a mix of diplomatic, economic, military, political and cultural strategies with respect to its foreign policy in order to recast the image of the US harmed by Bush Administration's approaches weighted on use of unilateral "military power" to this region. ${ }^{7}$ In addition to this, multilateralism seems to be one of the important elements of the new foreign policy approach of the US for this region: "America cannot solve the most pressing problems on her own, and the world cannot solve them without America". These words were expressed first by U.S. Secretary of State, Hillary Clinton, for evaluating the US foreign policy approach to the Middle East (IslamOnline.net, 2009).

${ }^{7}$ The ability to combine "soft power" and "hard power" into a winning strategy is smart power (Nye, 2006). 


\section{Assessment of Transatlantic Relationship between the EU and the US concerning the Middle East and North Africa Region in the Post- Cold War Era}

Europeans and Americans share common values and maintain close cultural, economic, social and political ties. Successive waves of immigration from every European country to the US which contributed also to the richness and diversity of American society during the past five hundred years is one of the major factors that have lead to this warm and close Transatlantic relations (European Commission, 1990). However, this close Transatlantic relations has been interrupted time to time. For instance, during the Yom Kippur War and the following first oil crisis (1973) the US backed Israel whereas many European states were more equivocal due to their dependence on Middle East oil. These Transatlantic frictions resurfaced during the Cold War period since the US and the EU disagreed sometimes over the right balance between defense and détente. However, these disagreements did not lead to deterioration of Western alliance, on the contrary Western alliance held firm and the Cold War was won. The challenge to the West from the Middle East and North Africa today is neither the same as that from the Soviet Union during the Cold War nor entirely different (Daalder, Gnesotto \& Gordon, 2006: 219).

With the collapse of Communism and disintegration of the Soviet Union, bipolarity and East-West axis disappeared as a defining feature of the international system. In this new system, the EU has become an actor of a more multipolar world and a "New Transatlanticism" emerged. With this new development, political links between the US and the EU were deepened and institutionalized. However, the sources of conflict in US-EU relations also appeared due to the emergence of distinct features of international relations after the Cold War. Disappearance of a Soviet threat as a force for unity in Western foreign policies, which led to Europe's dependence on US security guarantees, also eliminated the need for Europe towards compromise and conciliation in Transatlantic disputes (Blackwill \& Stürmer, 1997: 299). Moreover, emergence of new threats also changed the existing security understanding of the EU since military power is no more effective in solving issues such as environmental degradation, widening disparities between rich Northern and poorer Southern states, terrorism, organized crimes and failed states (Peterson, 1996: 8, 9).

In addition to this, the US and the EU are challenged by their declining collective power to dictate the terms of global trade and investment. For the economic issues, both the US and the EU now have more alternative 
partners with whom they can form alliances. In the defense and security field, the end of Cold War has also encouraged the EU to seek a European Security and Defense Identity (ESDI) which has a potential to undermine the role of NATO in the future if it includes the creation of a European army. ${ }^{8}$ The EU's efforts like developing a Common Foreign and Security Policy (CFSP) and ESDI which are based on "neo-Gaullist approach" which seek to enhance Europe's identity by distinguishing it from the US is another factor that contributed to loosening the transatlantic solidarity in the post-Cold War period (Blackwill \& Stürmer, 1997: 299).

In the post-Cold War period, the EU-US Presidential summits came into being as a result of the November 1990 Transatlantic Declaration in order to continue transatlantic alliance and to assess and develop transatlantic cooperation. The Transatlantic Declaration recognized the EU's pivotal role in both the political stability and economic reconstruction of Central and Eastern European Countries (CEECs). Moreover, it also stated a series of other issues such as the threat of proliferation of weapons of mass destruction (WMD), the situation in the countries of the former Eastern bloc, the war in Bosnia and later in Kosovo, the fragile peace process in the Middle East, and the need to safeguard economic growth and employment and the need for a joint response by the US and the EU to solve these issues. In order to meet these challenges, the EU-US Summit was held in Madrid, in December 1995 and the New Transatlantic Agenda (NTA) was adopted. The EU and the US pledged to work together "to promote peace, democracy and stability, foster economic growth and liberalization world-wide, meet global challenges such as terrorism and environmental degradation, and to build stronger non-governmental links between the people of Europe and the US". In other words, NTA provided a forum in which they may discuss and work together constructively to narrow their differences and reach a common basis (European Commission, 1995).

The scope of Transatlantic Partnership was broadened to allow for a dialogue between the EU and the US on many foreign policy issues and cooperation on international global challenges. Moreover, this dialogue has reinforced the convergence of their analysis and the perception of their common interests. This dialogue also allows them to act jointly and efficiently to enhance global stability and prosperity. However, this does not

${ }^{8}$ ESDP includes the common defense policy which in time lead to a common defence. It is developing in a manner that is compatible and coordinated with NATO (EUROPA (a), n.d.). 
preclude differences of appreciation and some divergence of policies based on national interest, historical perceptions, or other factors, affecting the EU's interests. The cooperative spirit and intense dialogue in the New Transatlantic Agenda (NTA) framework helps the EU and the US to address these differences in a constructive and forward-looking manner. In this sense, the Quartet (US, EU, Russian Federation, United Nations) can be regarded as one of the substantial joint efforts of the EU and the US working together to revive the Middle East Peace Process (MEPP) (European Commission, 1995).

Yet, diverging assessments of the impact of some of their policies sometimes overshadow the prospects of Transatlantic alliance in pursuit of their shared aims in the Middle East and North Africa region. For instance, in case of Iran, the EU has considered more chance of success for a a policy of constructive engagement than a strategy of isolation and economic sanctions. Hence, the US policy of "Dual Containment" of Iran and Iraq was not supported by the EU. Contrary to the US policy of "Dual Containment", they preferred policy of engagement through "Critical Dialogue" with Iran due to energy dependency and commercial attractiveness of these countries until Mykonos verdict (Blackwill \& Stürmer, 1997: 4). The EU also refused to join economic sanctions against Iran under ILSA (Iran and Libya Sanctions Act). Moreover, the EU complained about the US to the WTO due to the US' insistence that the EU should follow its lead in sanctions (ILSA) and labeled this insistence as illegal in international law and contrary to freedom of international trade (Ünver Noi, 2005: 81, 86). This led to another Transatlantic friction.

Fighting terrorism became a priority for the EU and the US before the September $11^{\text {th }}$ terror attacks to the US since at June 2001 summit for Transatlantic Cooperation both sides had already identified anti-terrorism as one of the five priority areas. After the September $11^{\text {th }}$ terror attacks to the US, this has become the overriding priority. The EU has worked with the US to build a global coalition against terrorism, and to establish joint initiatives designed to combat international terrorism (European Commission, 1995).

The EU took part in global actions aiming to fight against terrorism such as "freezing terrorist assets, implementing external assistance programs, supporting the efforts of third countries to comply with UNSC Resolution 1373 on the fight against terrorism and supporting political and cultural dialogue with those parts of the world where terrorism comes into being". The processes like the Euro-Mediterranean Partnership (EMP), which was 
already underway since 1995, gained more importance as an organization that aimed political, economic transformation of the region and establishment of intercultural dialogue to create a peaceful environment in this unstable part of the world (EUROPA, 2007b).

However unilateral preemptive military act in Iraq as a part of US policy to "fight against terrorism" without having a UN mandate violated UN resolutions and international law. It also led to transatlantic rift because the war on Iraq was seen as a risky mistake and unnecessary move by many Europeans contrary to the US' military act in Afghanistan (Aliboni, 2005: 1). Germany and France showed anti-US stand throughout the Iraqi crisis. The National Security Strategy of the US, which is based on strong unilateralism and principle of preventive war to impose its values from outside, was inconsistent with ESS(2003) which is based on the presumption that backward economic, social and political conditions in this region put threats or risks to its security (Aliboni, 2005: 2). The Iraq war thus showed that Washington pays little heed to European views on international political issues (Layne, 2004: 63).

Different perceptions of security and different foreign policy instruments used by them prevented closer transatlantic cooperation to emerge and moreover led to transatlantic rifts. Along with the war in Iraq, treatment of suspect individuals and terrorists in Guantanamo Bay, neglect and imbalance in the US policy towards the Arab-Israeli peace process (Hamilton, 2004: 71), and Lebanon and Syria question have become one of the other factors which negatively contribute to the rift between the transatlantic partners although both the EU and the US have the same aims such as to halt Syrian support for Hizbullah, terrorist access to Iraq via Syrian territory, democratization and liberalization. The gap between the EU and the US is greater on Syria since their approaches towards this country are different. The EU prefers policy of engagement through the Association Agreement signed between the EU and Syria whereas the US prefers policy of isolation (Daalder, Gnesotto \& Gordon, 2006: 223, 231).

The expectations about the initiatives such as Euro-Mediterranean Partnership-EMP (1995), Middle East Partnership Initiative-MEPI (2002), Broader Middle East and North Africa Initiative-BMENA (2004) in terms of encouraging both the EU and the US to act more cooperatively in pursuing their shared goals towards this region could not be met although the US and the EU converge on promotion of democracy and economic development in this region. As stated in the European Union-United States Relations paper, "the EU and the US as two largest economies in the world 
by working together, can promote their common goals and interests in the world much more effectively than they can separately' (European UnionUnited States Relations, sheet 2). The EU wants to be accepted by the USdominant power in the Middle East since WWII - as a "partner on equal terms". In this respect, the EU member states emphasized in the ESS, "Transatlantic relationship is irreplaceable. Acting together, the EU and the US can be a formidable force for good in the world. The EU's aim is to be an effective and balanced partnership with the US" (European Security Strategy, 2003).

As Cheema said 'the rift was a temporary phenomenon since these two powers are trading partners and enjoy considerable economic interaction including investments, strong security linkages and a collective security system like NATO, and finally their societies have common cultural roots and intellectual traditions' (Cheema, 2004: 9). When pro-American leaders, Sarkozy and Merkel, were elected as president and chancellor in their countries, France and Germany respectively, the rift, which had emerged at the time of Chirac and Schröder, was bridged. Obama's election as a President of the US and his administration's new approach which is based on smart power understanding (combination of hard power and soft power in Nye's term) and starting a "new beginning" in the Middle East contributed to this process.

\section{Analysis of the EU and the USA Rivalry concerning the Middle East and North Africa Region}

European-American relations in general terms is based on four images: 1) the image of complementarity 2) the image of competition 3) the image of balance of interests and 4) the image of divided Europe vis-a-vis the US (El-Sayed Selim, 2004: 227). Although their interests mostly converge as El-Sayed Selim argued 'to redesign the political architecture of the Middle East'(El-Sayed Selim, 2004: 227), their different approaches to have greater say in the region reveals the fact that there is a kind of a competition between the EU and the US.

The image of competition also exists in European-American economic control of markets. Some argue that the Middle East and North Africa (MENA), the US-sponsored project of 1994, was perceived as threat to the EU's economic interests in the region and led to the emergence of the EU led project the EMP in the same year (El-Sayed Selim, 2004: 227, 235). Since the end of the Cold War, the EU and the US have been jointly working to spread trade liberalization and privatization to the countries of 
the Middle East and North Africa in order to enable them to open their markets for their products. However, this created an environment in which the US and the EU have been competing (El-Sayed Selim, 2004: 234).

In 1993, the US suggested the establishment of a Middle East and North African system of economic cooperation. The countries of the region were persuaded to take part in the first MENA ministerial conference held in Casablanca in 1994 to formulate projects for regional cooperation. The EU was invited to the Casablanca Conference as an observer. They found out that they were being marginalized in the projected MENA cooperation. The same pattern persisted in the following three MENA conferences held in Amman in 1995, in Cairo in 1996 and in Doha in 1997. ${ }^{9}$ As the Europeans discovered that their economic interests in the region would be threatened by the 1994 the US-led project, they presented their own project for Mediterranean cooperation in the same year. The American backed MENA project collapsed in 1997 as a result of the election of the hawkish Netanyahu government in Israel. (El-Sayed Selim, 2004: 234).

In North Africa, 2003 witnessed European-American competition as the US and some southern European countries competed over who would have the upper hand in the economic domain of this sub-region. This was reflected in the revival of the European sponsored 5+5 Dialogue and the American economic project for North Africa. In 1990, five European countries Portugal, Spain, France, Italy and Malta initiated a dialogue with five Arab North African countries, Mauritania, Morocco, Algeria, Tunisia, and Libya. However, this dialogue was suspended by the European side after Security Council resolution on the American-Libya crisis was adopted (El-Sayed Selim, 2004: 236).

The Egyptians and the Americans took advantage of the suspension of the Dialogue to pursue their agenda. Because the Egyptians were excluded from the Dialogue, they called for the establishment of a pan-Mediterranean framework for cooperation entitled the Mediterranean forum. The Americans presented a proposal to establish a partnership with the North African countries entitled the American-Maghreb Partnership in June 1998 (El-Sayed Selim, 2004: 236).

\footnotetext{
${ }^{9}$ After the Anglo-American invasion of Iraq, the US renewed its economic drive in the region. In June 2003 President Bush suggested to establish a free trade area between Middle Eastern countries and the US.
} 
After the end of the American-Libya crisis in 2003, European countries expressed an interest in renewing the $5+5$ Dialogue. This was because of two factors; the American economic drive in the Maghreb countries that began in 1998, and disillusionment of the EU countries with the EMP. This partnership was plagued by the reluctance of the European to play an active role in the MEPP, and the insistence of the Arab countries to link EMP with the political settlement of the Arab-Israeli conflict. The Europeans thought that renewing the 5+5 Dialogue would signal to the Arab Mashreq countries that the EU could freeze the EMP and focus on sub-regional cooperation in the west Mediterranean, and to the Americans that North Africa is in the European socio-economic sphere of influence. Under strong French persuasion, 5+5 Dialogue convened a summit meeting in Tunisia in 2003. Two days before the summit, Colin Powell visited Morocco, Algeria and Tunisia to revive the 1998 American proposal. During this visit Powell suggested that Tunisia would be the headquarters of the American office to promote the American democracy project, in addition to the city of Dubai in the UAE. President Chirac denied that the Powell visit was a reflection of European-American competition in the Maghreb countries, arguing that Europe would like to help develop the Maghreb countries and it would be a good idea if the Americans also contributed to the achievements of this goal. Publicly, the EU leaders assert that there is no competition between them and the Americans in the North Africa. This statement applies mainly to the political-security sphere, but it is hardly applicable to the economic one (El-Sayed Selim, 2004: 236, 237).

The competition between the EU and the US went on when Barcelona Summit took place since the US was not invited as an observer to this summit. This summit irked the US due to implications of this process for the peace process, especially the Syria-Israel track. The following year, the EU was not consulted prior to the October 1996 Arafat-Netanyahu summit in Washington as a response to which the EU decided to name its own Middle East envoy and to approve an anti-Israeli communiqué in sixteen years (Satloff, 1997: 35).

Economic competition revealed itself with the establishment of a free trade area between the EU and the non-EU Euro-Mediterranean Partners since it might affect the US interests and as Khalilzad argues, it could have a detrimental effect on American-North African trade. This explains why the US officials were unhappy that they were not invited to the Barcelona meeting of 1995 and the US' Middle East Free Trade Area initiation (MEFTA) (Khalilzad, 1998: 209). Another indicator of rivalry between the 
US and the EU in this region is the EU's lack of strong willingness to cooperate in this region within the framework of the US-led initiative Broader Middle East and North Africa Initiative (BMENA) which gave one line reference to the EMP although they share similar interests and objectives (Aliboni, 2005: 7).

The rivalry between these two powers also exists in weapon sales to this area due to the US' preeminent position for weapon sales in comparison to the EU and in Arab-Israeli peace due to the US' leading role in the peace process and the EU's secondary role as a "payer" rather than a "player" (Khalilzad, 1998: 207). Since 1973, the US thus has assumed the leading role in the peace process in the Middle East. The EU has played relatively marginal political and diplomatic role, more prominent economic role in the region (Satloff, 1997: 30). ${ }^{10}$

\section{Conclusion}

Common values (democracy, rule of law, human rights and fundamental freedoms), close cultural ties between the EU and the US and their shared aims and interests in the the Middle East and North Africa region might lead to the perception that there is a transatlantic cooperation rather than competition in this region. The similarities between the threat perceptions given in both the EU's and the US' National Security Strategies and the aim of transforming the countries of this region into democratic and liberal ones also contribute to the perception that these two powers are in cooperation to achieve objectives set by them.

Although their approaches in terms of interests and aims seem complementary, there is a kind of competition between the EU and the US to have a control over this part of the world since being an effective global actor in international relations is also important for the EU. The establishment of the CFSP and the ESDP which seek to enhance Europe's identity by distinguishing it from the US is the major indicator of this aim of the EU. With this act, the EU did not contribute to transatlantic solidarity. In addition to this, the US' unilateral military approach to the region as a complementary to its political approach (BMENA) for "preventing

${ }^{10}$ The EU is major financial donor of the Palestinian Authority. The EU has two ESDP operations in the Palestinian Authority; The EU Border Assistance Mission at the Rafah Crossing Point (EU BAM Rafah), the EU Police Mission in the Palestinian Territories (EUPOL COPPS) since 2005 (Council of the European Union, n.d.). 
proliferation of WMD" and rapid transformation of this region into a "democratic" one is another indicator of this competition.

Although their interests and aims converge in terms of political and security issues their approaches to the resolution of problems stemming from this region diverge and sometimes keep the other side out of the process as witnessed in many cases: Madrid Middle East Peace Conference of 1991 and the US efforts to keep the EU outside of this process in order to prevent the EU to have a political role to play; initiation of the Barcelona Process without inviting the US as an observer as a Union's response to being excluded from US-led Madrid Peace Conference; the US' Iran and Libya Sanctions Act (ILSA) and the EU's refusal to implement those sanctions and its 'critical dialogue' with Iran contrary to the US' policy of "isolation" and "containment"; the US' unilateral war on Iraq; its negative impact on the EU member states and weakening the CFSP; initiation of the BMENA by mentioning only one line about the EMP (an initiative launched 9 years before with the similar objectives); and finally the EU's unwillingness to take active part in the BMENA projects.

These cases have revealed the fact that there is a kind of competition between the US and the EU in the Middle East and North Africa region. Economic concerns constitute the main determinant of this competititon. Since the end of the Cold War, the EU and the US have been jointly working to spread trade liberalization and privatization to the countries of the Middle East and North Africa in order to enable them to open their markets for the EU's and the US' goods. However, this created an environment in which the US and the EU have been competing. Free trade areas, which are trying to be established between the EU and each non-EU EMP partners, the US and the BMENA countries, might serve to kindle the economic competition that has emerged between these two powers. For instance, establishment of a free trade area between the EU and the non-EU EMP partners may affect the US' economic interests in these countries.

Moreover, the differences between the approaches of the EU and the US to this region -particularly the US' use of "military power" unilaterallywhich lead to transatlantic rifts, also contributed to much more competition rather than cooperation between the EU and the US. The US perefers to make "rapid transformation" by using its military superiority in this region in order to exert control over the oil rich countries of this region by creating pro-American regimes. On the other hand, the EU through "gradual transformation" understanding aims to shape the countries of this region in 
the EU's own image. These two different approaches of the EU and the US might explain the competiton between the EU and the US for this region.

However, the EU and the US initiatives such as EMP, MEPI, BMENA and the US military occupation of Iraq failed transform the countries of this region into democratic ones and to make them more secure and prosperous. The emerging major economies in the world like BRIC countries (Brazil, Russia, India and China) and their growing economies showed that they might be converted into new rivalries in the multipolar world if they achieve to convert their economic power into political power to have more say in the world. ${ }^{11}$ The latest meeting of the BRIC held in Yaktenburg indicated this possibility. Global economic and financial crisis, which has a great impact on economies of the EU member states and the US, made China world's largest merchandise exporter of 2009 passing Germany and the US. In this new international system, the US needs much more conciliatory policies rather than confrontation. Obama Administration gives signals of shift from Bush administration's clear-cut unilateral policies mostly based on "military power" to "smart power" which combines civilian power/soft power and military power/hard power together. The Obama administration's new approach to the Middle East and North Africa region as he stated in his Cairo speech along with France's changing attitudes towards the US and the NATO and the EU's economic interests in this newly emerging international system might facilitate Transatlantic cooperation and contribute much more to cooperation between the $\mathrm{EU}$ and the US rather than competition.

11 According to Goldman Sachs economist Jim O'Neill, these countries would overtake developed states like Britain, Germany and France by 2050. In other words the largest economies in the world may no longer be the richest by income per capita. Brazil, Russia, India and China could become a much larger force in the world economy (Wilson \& Purushothaman, 2003: 2). 


\section{References:}

Aliboni, R. (2005, May 10). Europe and the United States: Between Common Interests andDifferences. Lecture given at the Institut National de Stratégie Globale-INESG, Algiers.

Blackwill, R. D. \& Stürmer, M. (1997). Introduction. In R. D. Blackwill \& M. Stürmer (Eds.), Allies Divided: Transatlantic Policies fo rthe Greater Middle East (pp. 1-7), Cambridge, Massachusettes, London: The MIT Press.

Blackwill, R. D. \& Stürmer, M. (1997). Conclusions. In R. D. Blackwill \& M. Stürmer (Eds.), Allies Divided: Transatlantic Policies fo rthe Greater Middle East (pp. 299-305), Cambridge, Massachusettes, London: The MIT Press.

Cheema, P. I. (2004). General Trends in US and European Policies: A View from the Developing World. In N. A. Tahir (Ed.), US-European Relations in the Contemporary International Setting: Implications for the Developing World (pp. 1-15). Islamabad: B.C.C.\&T. Press University of Karachi.

Chomsky, Noam. (2007). Interventions. London \& New York: Penguin Books.

Council of the European Union (n.d.). European Security and Defence Policy (ESDP). Retrieved April 3, 2009 from http://www.consilium. europa.eu/showPage.aspx?id=268\&lang=en

Daalder, I., Gnesotto, N. \& Gordon, P. (2006). America, Europe, and the Crescent of Crisis. In I. Daalder, N. Gnesotto \& P. Gordon (Eds.), Crescent of Crisis: U.S. - European Strategy for the Greater Middle East (pp.1-4). Washington,D.C.: Brookings Institution Press.

Daalder, I., Gnesotto, N. \& Gordon, P. (2006). A Common U.S.-European Strategy on the Crescent of Crisis. In I. Daalder, N. Gnesotto \& P. Gordon (Eds.), Crescent of Crisis: U.S.- European Strategy for the Greater Middle East (pp. 219-242). Washington, D.C.: Brookings Institution Press.

Duchéne, F. (1972). Europe's Role in World Peace. In R. Mayne (Ed.)

Europe Tomorrow: Sixteen Europeans Look Ahead (pp.32-47). London: Fontana. 
Elgström, O. \& Smith, M. (2006). Introduction. In O. Elgström \& M. Smith (Eds.), The European Union's Role in International Politics: Concepts and Analysis (pp. 1-10). Aningdon \& New York: Routledge.

El-Sayed Selim, M. (2004). European and American Approaches Towards the Palestinian and Iraqi Questions: Areas of Convergence and Divergence. In N. A. Tahir (Ed.), US-European Relations in the Contemporary International Setting: Implications for the Developing World (pp. 225-255). Islamabad: B.C.C.\&T. Press University of Karachi.

European Commission (1990). Transatlantic Declaration on EC-US Relations, 1990. Retrieved March 20, 2008 from http://ec.europa.eu/ external_relations/us/docs/trans_declaration_90_en.pdf

European Commission (1995). The New Transatlantic Agenda. Retrieved March 20, 2008 from http://ec.europa.eu/external_relations/ us/docs/new_transatlantic_agenda_en.pdf

EUROPA (a) (n.d.). European Security and Defence Policy (ESDP). Retrieved March 2, 2009 from http://europa.eu/scadplus/glossary/ european_security_defence_policy_en.htm

EUROPA (b) (2007). Summaries of EU Legislation, Freezing Funds: Lists of Terrorists and Terrorist Groups. Retrieved March 20, 2008 from http://europa.eu/legislation_summaries/justice_freedom_security/fight_a gainst_terrorism $/ 133208$ _en.htm

European Security Strategy (2003, December 12). A Secure Europe in a Better World. Retrieved April 12, 2009 from http://ue.eu.int/uedocs/cmsUpload/78367.pdf

European Union- United States Relations. European Commission, Directorate - General for External Relations, Luxembourg: Office for Official Publications of the European Communities.

Hamilton, D.S. (2004). Reconciling November 9 and September 11. In C. V. Balis \& S. Serfaty (Eds.), Visions of America and Europe: September 11, Iraq and Transatlantic Relations (pp. 70-87). Washington, D.C.: The CSIS Press.

Ikenberry, G. J. (2002, September-October). America's Imperial Ambition. Foreign Affairs, 81 (5), 44-60.

IslamOnline.net (2009, January 13). US to shift to smart power: Clinton. Retrieved August 2, 2009 from http://www.islamonline.net/servlet/ 
Satellite $\mathrm{c}=$ =Article_C\&pagename=Zone-English-News/NWELayout\& cid $=1231760489978$

Khalilzad, Z. ( 1998). Challenges in the Greater Middle East. In D. C. Gompert \& F. Stephen Larrabee (Eds.), America and Europe: A Partnership for a New Era (pp. 191-217). Cambridge: Cambridge University Press.

Kreft, H. (2005, Spring). The Foreign Policy of George W. Bush: More of the Same in the Second Term?. Perception Journal of International Affairs, X (1), 63-78.

Layne, C. (2004). Iraq and Beyond: "Old Europe" and the End of the U.S. Hegemony. In C. V. Balis \& S. Serfaty (Eds.), Visions of America and Europe: September 11, Iraq and Transatlantic Relations (pp.46-67), Washington, D.C.: The CSIS Press.

Maull, H.W. (2005). Europe and the New Balance of Global Order. International Affairs, 81, 4, 775-799.

Nye, J. (1990, Autumn). Soft Power. Foreign Policy, 80 (Twentieth Anniversary), 153-171.

Nye, J. (2006, August 19). In Mideast, the Goal is 'Smart Power'. Retrieved June 14, 2009 from The Boston Globe http://www.boston.com/ news/globe/editorial_opinion/oped/articles/2006/08/19/in_mideast_the_g oal_is_smart_power/

O'Gorman, F. (2004). The European Union, the United States and the Middle East: A Troubled Trio?. In P. G. Xuereb (ed.) The European Union and the Mediterranean: The Mediterranean Challenge (pp. 131147). Malta: University of Malta.

Peterson, J. (1996). Europe and America: The Prospects for Partnership. London \& New York: Routledge.

Rhein, E. (1997). Europe and the Greater Middle East. In R. D. Blackwill and M. Stürmer (Eds.), Allies Divided: Transatlantic Policies fo rthe Greater Middle East (pp. 41-60) Cambridge, Massachusettes, London: The MIT Press.

Satloff, R. (1997). America, Europe and the Middle East in the 1990s: Interests and Policies. In R. D. Blackwill and M. Stürmer (Eds.), Allies Divided: Transatlantic Policies for the Greater Middle East (pp.7-39). Cambridge, Massachusettes, London: The MIT Press. 
Sjursen, H. (2005). The EU as a 'normative power': how can this be? Retrieved June 30, 2009 from http://aei.pitt.edu/3169/01/EUSA_ Conference_2005_Sjursen.pdf

Smith, K. E. (2003). European Union Foreign Policy in a Changing World. Cambridge: Polity Press.

Ünver Noi, A. (2005, Spring). Iran's Nuclear Program: EU's Approach to Iran in comparison to US' Approach. Perceptions Journal of International Affairs, X (1), 79-95.

Ünver Noi, A. (2007). Avrupa'da Yükselen Milliyetçilik. İstanbul: IQ Kültür, Sanat ve Yayıncılik.

Walt, S. M. (2005). Taming American Power: The Global Response to U.S. Primacy. New York \& London: W.W. Norton \& Company.

Wilson, D \& Purushothaman, R. (2003, October 1). Dreaming with BRICs: The Path to 2050. Global Economics Paper No. 99. Retrieved August 2, 2009 from http://www2.goldmansachs.com/ideas/brics/book/99dreaming.pdf 